\title{
Quedarse en casa para llegar muy lejos
}

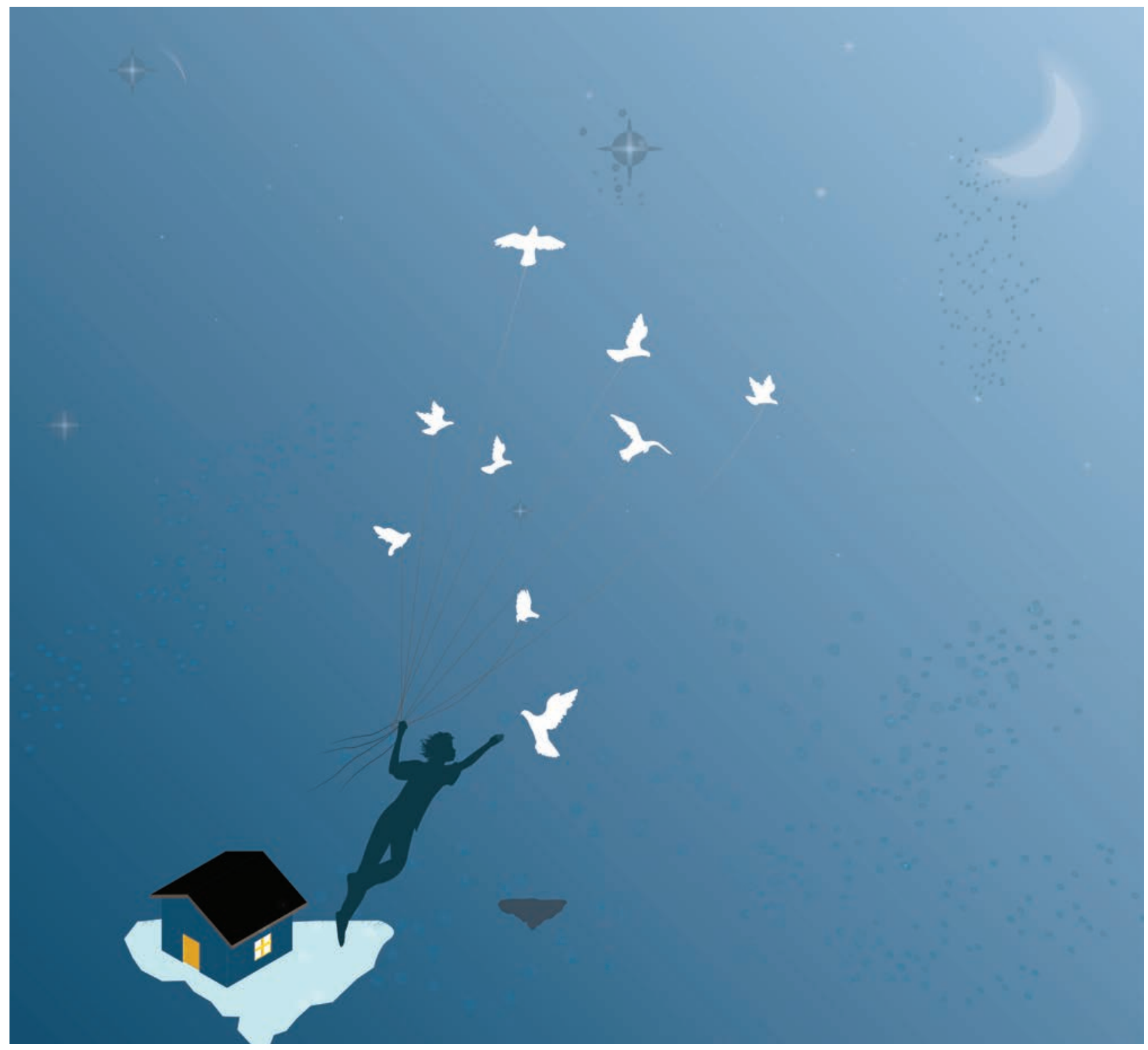

Una experiencia vital sin precedentes, los móviles y las pantallas, tan prohibidas con frecuencia, ahora son la norma. Energía encerrada, amigos a distancia, profes cuya voz se escucha en casa, sorpresas. Nueva vida familiar, colaboración, autonomía, contacto cotidiano, más sorpresas. ¿Cómo lo recordarán cuando haya pasado el tiempo? Ahora, todavía sin salir de casa, nos escriben sus sensaciones desde la Primaria hasta la Universidad. Hablan los estudiantes. 


\section{Carmen Casado Núñez}

\section{[4. Primaria $]$}

Hace unos meses los niños de mi clase no paraban de hablar de un virus que se llamaba "coronavirus", yo no entendía de qué estaban hablando y les pregunté qué era eso. Ellos me respondieron que era un virus que se había extendido desde China y era grave porque, aunque pareciera una gripe, podías llegar a tener síntomas muy graves. Unos días después, yo me levanté y pregunté a mi cuidadora por qué no nos había despertado para ir al cole

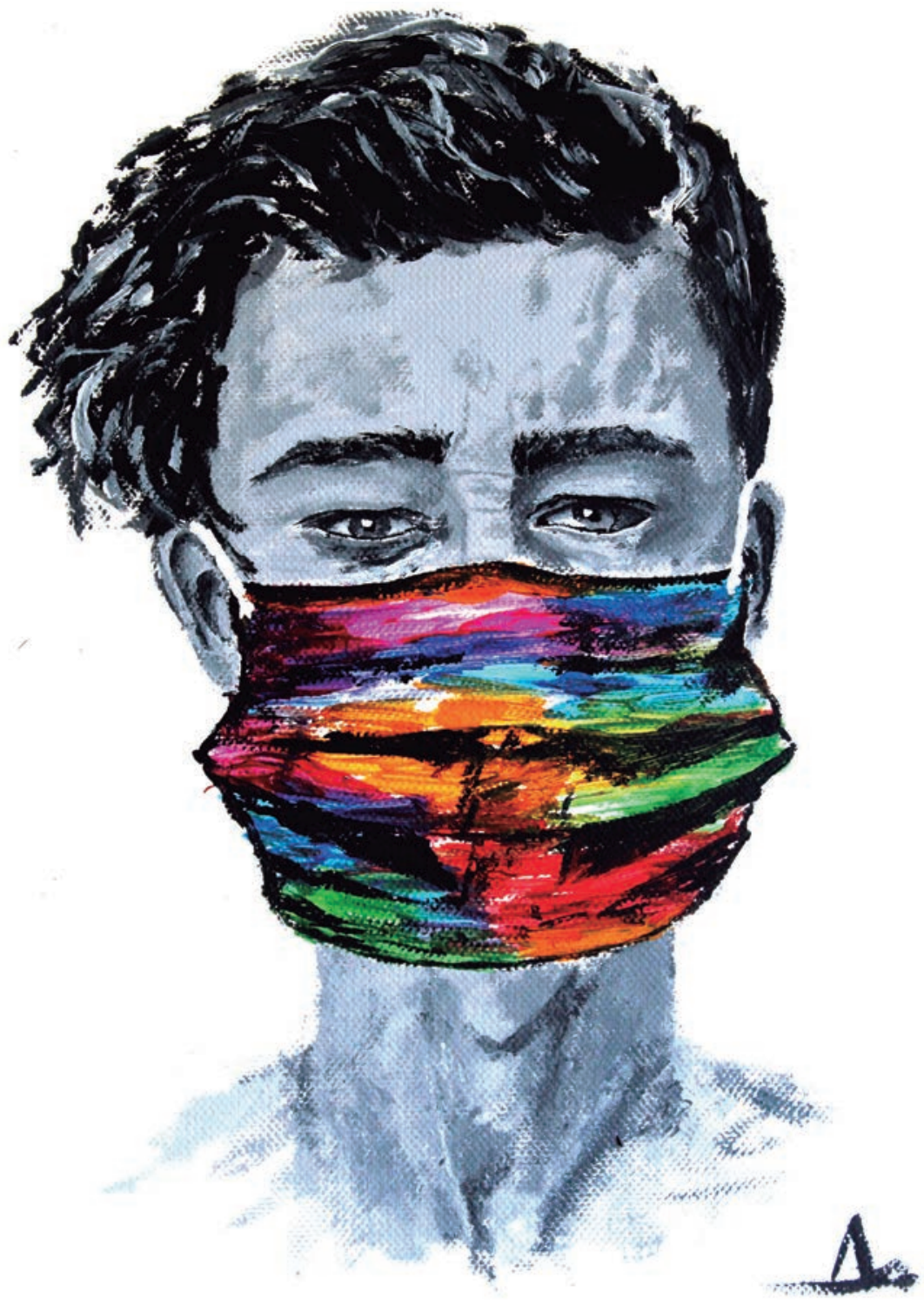

Ana $\left(2 .{ }^{\circ}\right.$ Bachillerato, Centro de Formación Padre Piquer) y ella me dijo que el presidente del Gobierno había dicho que a partir del miércoles no íbamos a ir al cole.

Yo pensé que no ir al cole podría ser estar mucho tiempo en el parque, divirtiéndome, ir a casa de mis primos, y muchas cosas más; sin embargo, enseguida empezamos a oír noticias de los sanitarios en las que decían: "quédate en casa". Desde ese día, empecé a hacer las tareas que Arturo, mi profe, nos colgaba en el blog, a hablar con él por videoconferencia, a hacer bromas con mi hermano, a jugar a juegos de mesa y descubrir lo divertido que es jugar todos en familia. He comprobado lo importante que es que todos en la familia estemos sanos, y la importancia que tiene obedecer a los que saben de esto, en este caso a los sanitarios. Yo, además, celebré mi cumple en esta situación, el 27 de marzo cumplí 10 años. Pensé que no sería nunca uno de mis mejores cumpleaños, en cambio, cuando acabó el día había vivido tantas experiencias bonitas y divertidas que se me vino a la cabeza apuntarlo en mi diario para no olvidarlo nunca. Y yo lo definí como "un cumpleaños de 10".

Aunque echo de menos el cole, la verdad es que estoy muy orgullosa de las cosas tan chulas que nuestros profesores nos están mandando. Cuando hablo con mis amigas por videollamada nos las enseñamos y vemos qué ha hecho cada una. Después de haber estado unos días en casa, empezamos a hacer un gesto muy bonito: salir al balcón para aplaudir a los sanitarios y fue un momento en el que conocí a gente que nunca había visto y que, sin embargo, era muy amable. i¡Cuando volvamos a la normalidad voy a poder contar más cosas que las que me pasan aproximadamente en un año!! • 


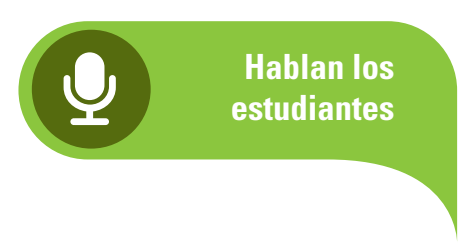

Desde hace seis semanas no tengo cole y trabajamos en casa. Yo al principio me sentía muy desubicado, cada vez voy mejor y desarrollo técnicas de trabajo nuevas. A veces, me apoyo en mis amigos para hacer algunas tareas y viceversa. Yo sigo la ruti-

\section{Luis Watty Núñez}

[6. ${ }^{0}$ Primaria ]

na de clase: en Matemáticas y en Lengua, los lunes hago también lo del martes y así el viernes puedo dejarlo para hacer lo que no me ha dado tiempo los demás días.

Desde el iPad, a veces, nos dan clases virtuales. A mí personalmente me ayuda mucho a ponerme al día con mis compañeros. Mis profesores me ayudan mucho, me dan bastante apoyo y fuerza para seguir trabajando, tengo toda la confianza en ellos y siempre están ahí si tengo alguna duda. A mí me está costando mucho Science, siempre me ha costado, pero ahora bastante más de lo que me costaba antes pese a que la profe me está ayudando mucho.

Cada día me centro más en la constancia porque ese está siendo mi punto débil. Me parecen una tontería los exámenes porque, aunque yo no lo hago, hay grandes tentaciones de copiar y hacer un uso fraudulento de los apuntes. Un problema más que añadiría a la cuenta de fallos de trabajar desde casa son los problemas de conexión con la wifi algunas veces.

Yo tengo perro y tengo mucha suerte porque de vez en cuando puedo salir a la calle a pasearlo y después de hacer los deberes, ayudo en casa a mi padre, mi madre y mi hermano mayor. He aprendido a hacer otras tareas como fregar o poner el lavaplatos y la lavadora. Echo de menos

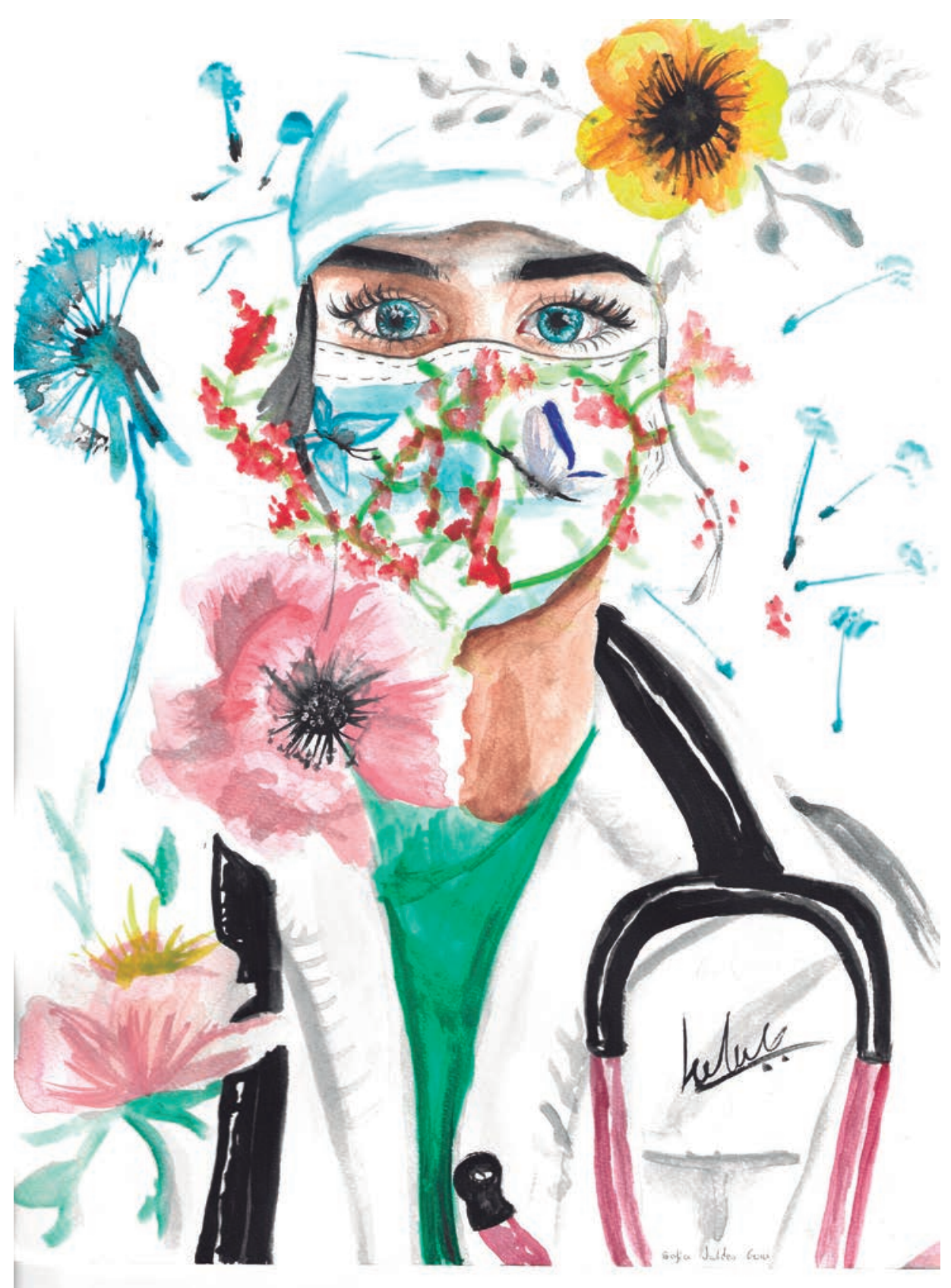
jugar al baloncesto en las canastas del cole, pero sé que queSofía J. G. (4. ${ }^{\circ}$ ESO) dándonos en casa ayudamos a que todos los que están malos se curen antes $•$ 


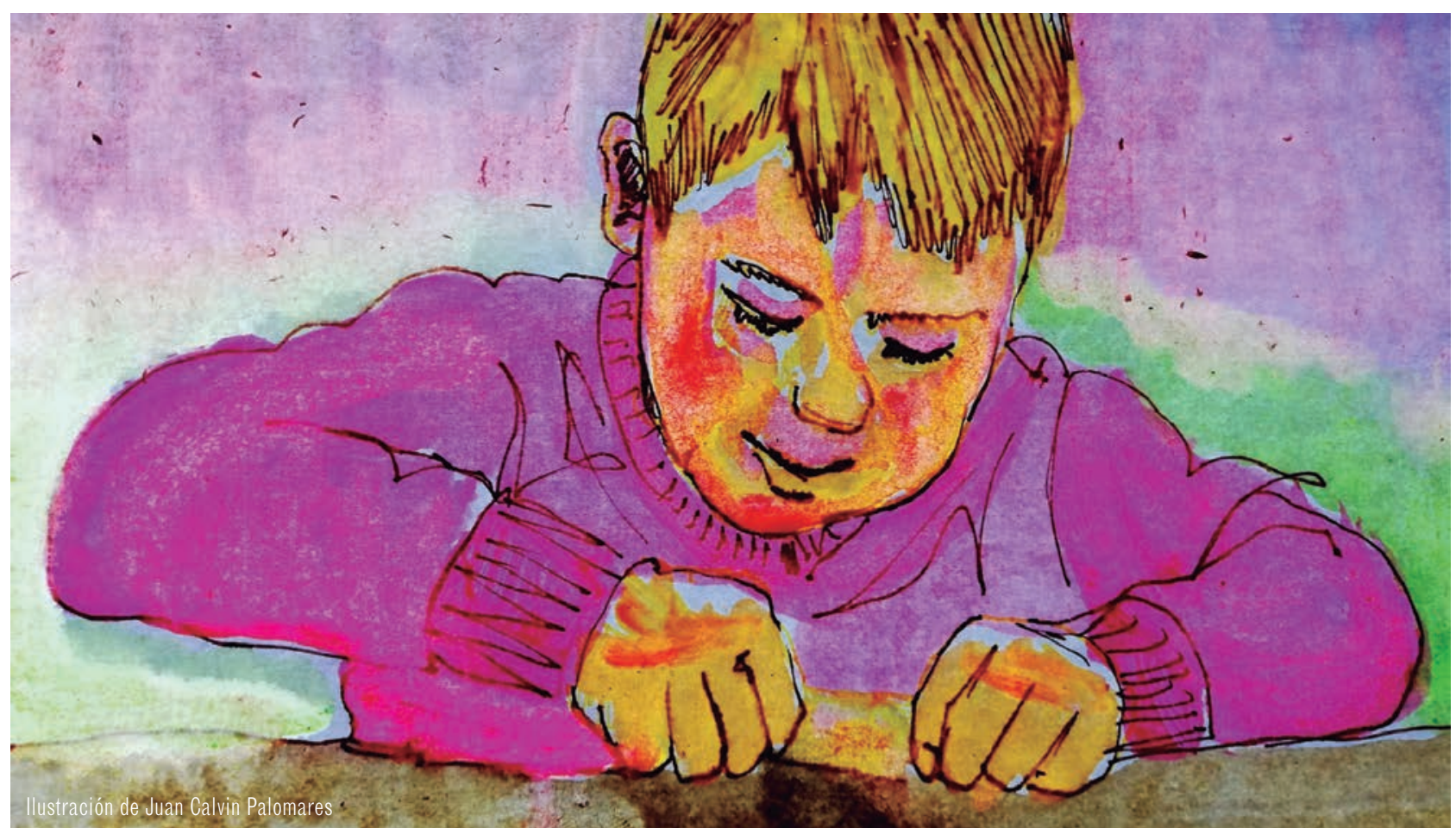

\section{Jorge Carnero Rodríguez}

Buenos días, me llamo Jorge, soy un alumno de $2 .^{\circ}$ de la ESO del Centro de Formación Padre Piquer y os voy a contar cómo es la cuarentena para mí.

El día que llegué a casa después del colegio me enteré por las noticias que el miércoles no íbamos a tener clases normales, sino que serían desde casa. Al principio sentí que eran una especie de vacaciones, pero luego me di cuenta que esto podía suponer la pérdida del curso. El martes cuando llegué a clase me quitaron ese miedo porque me dijeron que el curso no estaba perdido, sino que nos evaluarían con los ejercicios que nos iban a ir mandando.

Los primeros días fueron bastante complicados en cuanto a organización, ya que en mi casa estábamos los cuatro trabajando en la mesa de salón, en la que no había espacio suficiente para los cuatro y encima con las reuniones que tiene mi padre, que no nos dejaba hablar cuando él estaba en una reunión. ¡Y el tema de la wifi...! Que eran tantos dispositivos electrónicos utilizando la wifi que iba muy lenta. Así que decidí meterme en mi habitación porque iba a dar igual, la wifi ya iba lenta, así que por lo menos tenía mi espacio.

También los profesores nos han seguido evaluando con los ejercicios que nos han mandado y con algún formulario de Google en forma de examen. Así que, aunque sea un curso bastante extraño, no está perdido.

Y tampoco perdemos la relación con nuestros compañeros y profesores ya que tenemos la suerte de que en el iPad nos han puesto la aplicación de Google Hangouts y podemos seguir hablando y vernos las caras Ilamándonos entre nosotros. Y así no nos volvemos locos por estar todo el día entre las cuatro paredes de casa y siempre con las mismas personas.

En conclusión: estos días están siendo bastante estresantes, pero felices porque conoces mejor a tu familia y al final todo se solucionará • 
Hacía ya varias semanas que el revuelo social y sanitario comenzaba a acrecentarse, pero no nos imaginábamos que llegaría a tanto. Al menos yo no quería adelantar acontecimientos. Tampoco había alarmismo en clase. El martes 10 de marzo fue un día extraño para todos y todas cuantos nos aventuramos a ir a clase el día siguiente a la noticia del cierre inminente de las aulas a causa de la COVID-19. Creo que el momento en que nos encontrábamos todas alrededor de un portátil, escuchando en directo el comunicado de las 12:00, será algo que recordaremos dentro de muchos años. A cada anuncio indagábamos en la cara de Paloma que, como el resto de docentes y a pesar de ser nuestra tutora, se enteraba en el mismo momento que nosotras de las primeras decisiones con respeto a la cancelación de las clases presenciales.

Desde entonces han pasado muchas cosas. Nuestro entorno, aparentemente más estático que nunca, no ha dejado de cambiar día a día y nos apremia por ello a descubrir recursos nuevos para hacerle frente. ¿Informáticos? Sí, indispensables en este tiempo. iY dando gracias a cuantos los hacen posibles! Son una forma eficaz de mantenernos conectados... pero que no servirían de nada si no hubiese alguien que quiere estar cerca a través de ellos. Esto es lo que más me ha conmovido y algo que quiero recordar.

Había un temario programado, entregas grupales estratégicamente propuestas, proyectos minuciosamente pensados para transmitir todas las competencias al alumnado... j|ncreíble lo que puede llegar a trastocar algo que ni siquiera puede llamarse célula! Todo eso era muy importante; tenía detrás el tiempo y el esfuerzo de nuestros profesores y profesoras.

Es verdad, algunas cosas en la vida se aprenden por conceptos, en un temario con un contenido estructurado, etc. Pero en estos días se hace más evidente que todos y todas aprendemos, al igual que enseñamos, en esta extraña prueba. Sí, es un "parón", pero la vida no permite pausas, y se abre paso con potencia en este tiempo donde todo se comparte en lugares reducidos y a larga distancia. Los "espacios" que solían estar claramente delineados, encuadrados en su contexto y separados por varias líneas de metro, ahora, a unos cuantos kilómetros de distancia, están todos aquí, en mi habitación, y aparecen a través de la pantalla, como la única posibilidad de "contacto" para hablar, escuchar, echar de menos, reír, estudiar, asistir a clase, entregar trabajos, resolver dudas, compartir el agobio de la incertidumbre... y así, ensanchar el ánimo aunque no se amplíen las paredes.

Pero no sé si las personas que al otro lado de la red ponen todo su empeño en que aprenda los conceptos se dan cuenta realmente de cuánto más me están enseñando en los detalles de entrega profesional y humana: en rompecabezas de conexiones y videollamadas personalizadas, horarios que se cruzan en los diferentes ámbitos profesionales, planificaciones reinventadas con cada dificultad... En la cercanía afectuosa y sincera, acompañando los momentos de dolor, angustia e incomprensión. Pero creo que les sorprendería lo que también enseñan las pinceladas de vida cotidiana que comparten con nosotras - las circunstancias de cada uno y cada una - por las que también nos piden la

\section{María Ciria Gómez}

\section{[1.CFGS Integración Social ]}

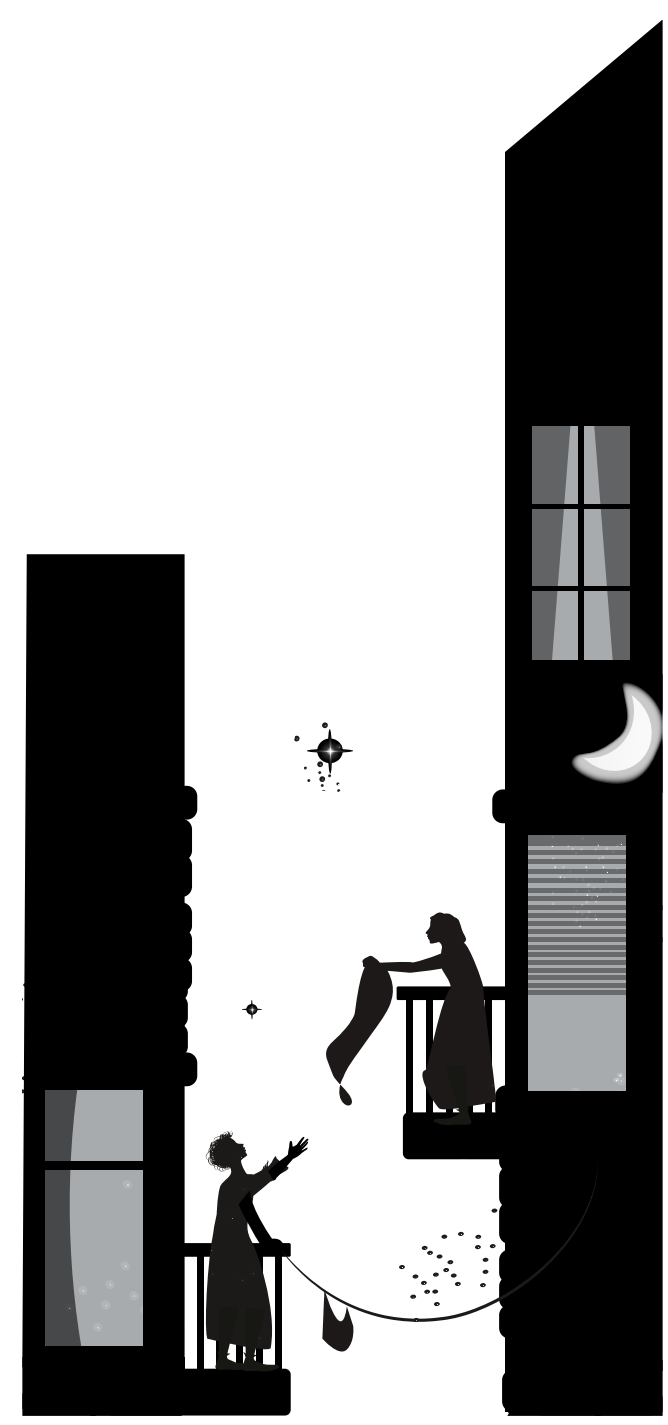


comprensión y flexibilidad propias de la madurez. Pues aparte de docentes y profesionales del sector social son hijos/as, madres, padres, tienen un familiar enfermo, emplean parte de su tiempo en un voluntariado en favor de los que más sufren las consecuencias de la enfermedad, siguen formándose como profesionales para poder ofrecer cada día un poco más, o se están poniendo al día del funcionamiento de las redes para llegar a mi alcance en estas circunstancias...

Para mí, son esas acciones de coherencia y entrega las que convierten a estas personas en referentes y dan peso a sus palabras. En mí reanudan la ilusión de una buena formación: para el bien de las personas con las que me encuentre en la vida en un mañana que espero no sea ya lejano •

\title{
Pablo Jaramillo Muñoz
}

\author{
[2. ${ }^{\circ}$ de Bachillerato ]
}

Estudio 2. ${ }^{\circ}$ de Bachillerato en el Centro de Formación Padre Piquer y junto a miles de estudiantes más, estos días estoy siguiendo con mi curso online. Para mí y para mis compañeros es una situación excepcional en la que tenemos que poner todos una atención especial.

Cada mañana me conecto a internet para ver las tareas que han ido añadiendo mis profesores, las videoconferencias que han programado y sus mensajes. Con todo esto, puedo organizar mi día con el tiempo de trabajo y el tiempo de "ocio". Por otra parte, es complicado seguir todas las asignaturas, ya que hay algunas que nos gustan más y otras que nos gustan menos, por lo que debemos hacer un esfuerzo especial en seguir estas últimas.

Una de las motivaciones para estudiar estos días es seguir el trabajo con varios compañeros, bien por videoconferencias o por mensajes, de esta forma podemos ayudarnos y a su vez, hacer el trabajo más entretenido. También alegran las clases por videoconferencia, ya que es un momento en el que vuelves a ver a todos tus compañeros y profesores.

En 2. de Bachillerato, también hemos tenido días en los que estábamos algo desconcertados con el tema de la selectividad, el final de curso, la graduación y más preocupaciones. Los grupos de clase se inundaban de mensajes y de artículos de diferentes medios, y esto hacía que se sembrase el caos entre nosotros. Pero poco a poco vamos teniendo noticias de cómo vamos a acabar el curso, de como haremos la selectividad...

Este tiempo de confinamiento, lo aprovecho para hacer con mi familia cosas que no haríamos en nuestras rutinas: cocinar, jugar a juegos de mesa, charlar más... También para dedicar más tiempo a mí mismo, a leer, a reflexionar, a ver series y a terminar lo que nunca acabé.

La situación que estamos viviendo entristece ya que son miles las víctimas que está dejando esta pandemia, pero también por todas las familias que están pasando por momentos económicos delicados. Seguro que esto nos ayuda a valorar más lo que tenemos y a las personas que queremos $•$ 
Fue todo demasiado rápido. De un día para otro nuestro día a día, nuestras vidas, se detenían y todo se resumía en una sola frase: "quédate en casa". Al principio no parecía algo tan serio, es más, algunos pensábamos que nos iríamos de vacaciones; pero poco a poco nos fuimos dando cuenta de que este virus nos superaba y que realmente se trataba de algo muy importante. Los días han ido pasando, unos se hacían más cortos y otros más largos, unos más entretenidos y otros en los que te quedabas mirando el reloj y te dabas cuenta de que las agujas seguían estando en el mismo lugar que hacía tres horas... Mientras tanto, son miles y miles las personas que han luchado y que siguen haciéndolo para poder volver a lo de antes.

Dicen que todo pasa por algo, que todo depende de cómo lo mires, y aunque sea una época muy dura intento ser positiva. Por una vez nos hemos parado, y una vez me dijeron que pararse es llegar más lejos. Tendemos a vivir tan deprisa que no somos conscientes de lo que nos rodea, en definitiva, de lo efímera que es la vida. Estas semanas, esa pausa nos ha permitido apreciar el gran fondo que tienen las personas. El fondo de los sanitarios dándolo todo por aquellas personas enfermas, las cartas anónimas enviadas a los hospitales para transmitir pequeñas dosis de cercanía y cariño a los pacientes, nuestros aplausos a las $20.00 \ldots$ Pequeños momentos que nos han permitido valorar lo que normalmente pasaba desapercibido.

Cuando este confinamiento Ilegue a su fin y empiece la desescalada, esto marcará un antes y un después para todos nosotros. El virus nos ha demostrado que no importa dónde vivas, quién seas o a qué dediques tu vida. Todo eso pasa a un segundo plano y al final aquello que de verdad importa es que somos personas, personas capaces de dar lo mejor de nosotros mismos a los demás. Capaces de frenar un mundo entero por y para los que lo necesitan.

Ahora nos toca seguir siendo pacientes y no olvidarnos de la importancia que tiene apreciar cada momento y a cada persona, ya que esta experiencia nos ha enseñado que apenas tenemos control sobre nuestras vidas. Sé que ha sido y es difícil, pero entre todos podemos frenar esta pandemia y comenzar a valorar esos pequeños aspectos de la vida que la rapidez y las ansias nos impedían ver •

\section{María Riccardi Roca de Togores}

\author{
[2. ${ }^{\circ}$ Doble Grado de Educación \\ Primaria e Infantil ]
}

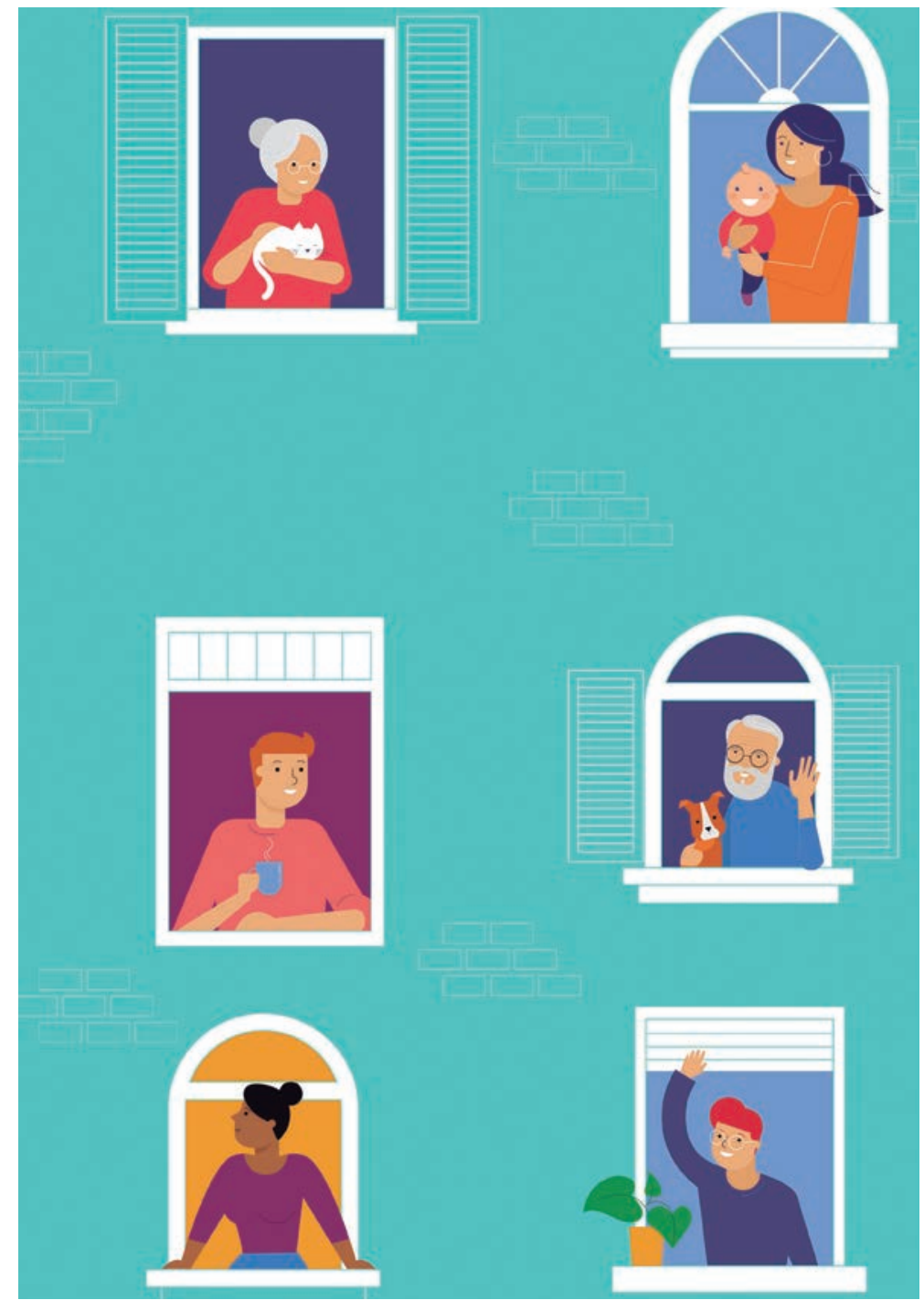




\section{Andrés Barrera Gibello}

\section{[ 3. ${ }^{\circ}$ Grado en Educación Primaria ]}

Creo que hablo en nombre de todos cuando digo que las imágenes y noticias que nos han ido llegando a lo largo de estas últimas semanas son desoladoras. Quizá, muchos de nosotros hemos llegado a preguntarnos qué va a ser del mundo entero cuando esto acabe, porque, efectivamente, no parece que las cosas vayan a ser igual que antes.

Hemos visto, también, cómo esto está afectando al mundo educativo. La sensación general, tanto de estudiantes como de profesores es de desconcierto; en especial, para los alumnos más vulnerables que ni siquiera tienen la oportunidad de asistir a las clases online. Creo que el golpe tan fuerte que ha dado esta crisis sanitaria, y el golpe tan fuerte que va a dar la próxima crisis económica, es una oportunidad que tenemos los estudiantes y los profesionales de la educación para reivindicar y luchar por nuestros derechos. Nos hemos visto afectados por un sistema educativo que no ha sido capaz de poner solución a nuestros problemas y que ha agravado las desigualdades socioeconómicas del país.

Es una realidad que esta situación ha afectado, sobre todo, a las familias y estudiantes más vulnerables. Por una parte, hay un gran número de familias en nuestro país que no disponen de los materiales básicos para poder continuar las clases en formato online, o lo hacen de manera muy reducida. Por esta razón, el abandono escolar por parte de estos estudiantes es un hecho, y el sistema educativo no ha puesto ninguna solución a estos problemas, de ahí el nivel de incertidumbre de estudiantes, profesores y familias. Por otra parte, los estudiantes que sí tienen la oportunidad de seguir recibiendo su educación académica se están viendo desbordados por la sobrecarga de trabajo y sufriendo más situaciones de agobio y estrés que antes; o, todo lo contrario, un abandono por parte de los centros y profesores al no saber qué hacer, pues, como ya hemos dicho, no se están ofreciendo medidas coherentes a la situación que estamos viviendo. En suma, un caos educativo al que no se está dando respuesta por parte de las autoridades.

La situación es grave y muy preocupante; sin embargo, pasará. Pasará, a pesar de las consecuencias. Es una obligación luchar por un futuro mejor. Si algo hemos podido aprender estos días es que solo el pueblo salva al pueblo, por eso me gustaría acabar estas líneas dando las gracias a todos los trabajadores que se están jugando la vida estos días para que el país no pare: sanitarios, cajeros, transportistas, basureros, conductores del transporte público, repartidores... A todos vosotros, igracias! Luchemos juntos por un futuro mejor para la clase trabajadora, la verdadera salvadora del pueblo

«En España lo mejor es el pueblo. En los trances duros, los señoritos invocan la patria y la venden; el pueblo no la nombra siquiera, pero la compra con su sangre y la salva» (Machado, 1937, Carta a David Vigodsky). 
"Guardarlo en el bolsillo para no estar pendiente de la hora»

La gran Noche. Relato de un náufrago

(G. García Márquez)
Natalia Flores Camarero

[3. ${ }^{\circ}$ Grado de Educación Primaria ]
"Tengo que cargar el ordenador y no olvidarme de la tartera, otra vez". Ya había escuchado rumores acerca del confinamiento, pero mi mente seguía empecinada en que tendría que ir a la universidad. Sin embargo, en las noticias anunciaron definitivamente la necesidad de recluirnos en nuestras casas.

En un primer momento, la incertidumbre de no saber cuándo saldríamos de nuevo me inquietaba. Ahora bien, ¿servía de algo ese malestar? Fue, entonces, cuando decidí crearme una rutina para aprovechar el día: hacer tareas universitarias, meditar, leer, hacer ejercicio, llamar a los amigos y a las amigas... y vencer, digo jugar, con mi madre a las cartas.

Me había creado un calendario que me permitía organizarme a mi manera porque, por una vez desde hacía mucho, sentí que tenía tiempo; un tiempo que deseaba aprovechar al máximo. Eso sí, mi alegría se desvanecía cuando veía el telediario y, más aún, tras recibir una llamada: mi tía había dado positivo. Cada día recibíamos noticias y esperábamos impacientes un mensaje suyo, pues el desasosiego nos limitaba a la hora de continuar nuestra covidrutina. Tras una semana alarmadas, el teléfono sonó. Era ella, jera ella! Se había recuperado; y, al igual que ella, otras personas anónimas que regresaron felizmente a sus hogares.

Después del susto, retomé mi rutina. También bajaba a la calle, para hacer la compra. Las hileras de gente eran tan largas que veía cómo me empezaban a salir canas... Cada persona separada a un metro y medio, las miradas más alejadas aún. Se me hacía extraño presenciar ese panorama; hasta echaba de menos las discusiones entre individuos que se quejaban porque uno de ellos se había colado en la fila. Una de las veces, pagué con la tarjeta de crédito, entregada a la cajera con unos guantes de plástico que me cubrían las manos (del tinte del pelo de mi madre, porque no teníamos otros). Tras entregarme el tique de la compra, le agradecí su atención y ella me sonrió bajo una mascarilla que alejaba esa proximidad que yo tanto añoraba. Subí a mi casa e hice una lista de pros y contras del confinamiento. Os la redacto, queridos lectores:

Contras: fallecimientos, negocios en quiebra, no poder ver a mis amigos, ver las calles sin gente, sin vida, y no poder abrazar a mi padre.

Pros: ejercicio y leer con un amigo en videollamada, meditar, estudiar con una compañera por Skype, dibujar, jugar con mi madre, llamar a mi padre y a mis tías, jugar a partidas online con mis colegas, cocinar con mi madre (menos cuando se enfadaba porque manchaba la cocina o quemaba alguna receta).

Concluyendo, realmente creo que este periodo me ha permitido valorar más la compañía de la gente. Al fin y al cabo, una pantalla no sustituye el contacto visual, una sonrisa cercana o un abrazo •

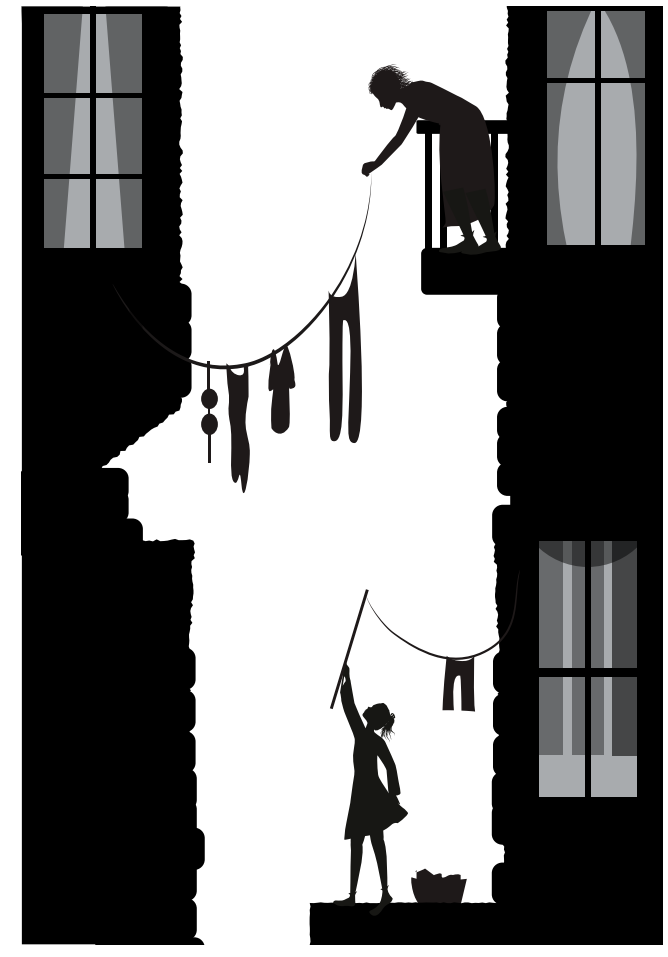




\section{Cristina Cano Antón}

\section{[ 3. Doble Grado de Educación Infantil y Primaria ]}

¡Impensable!

Pero, por desgracia, se hizo realidad. Si hace un tiempo alguien nos hubiera dicho que esto podía ocurrir, no lo habríamos creído. Sin embargo, hace un par de meses que el coronavirus se ha instalado entre nosotros e, ineludiblemente, nos hemos tenido que adaptar a él y a lo que ello conlleva. Uno de los sectores que se ha tenido que amoldar a esta nueva situación es el de la educación, del cual, como estudiante de Educación Infantil y Primaria, me siento parte.

Me gustaría aprovechar este espacio para contar de forma breve mi experiencia. Los días previos al confinamiento contemplaba como posible la suspensión de las clases en la universidad. Por eso, cuando se nos comunicó la noticia, no me pilló desprevenida. El primer cambio para mí fue volver a mi casa en Galicia, con mi familia.

A partir de aquí, a nivel académico, todo ha sido un continuo proceso de adaptación a la nueva metodología adoptada por la universidad. Lo que más he lamentado ha sido el no poder finalizar las prácticas que estaba realizando este curso. Pero, por lo demás, la experiencia está siendo más satisfactoria de lo que esperaba. Una ventaja que he notado ha sido el ahorro en tiempo al evitar los largos desplazamientos por Madrid para acudir a mi facultad, lo cual me permite disponer de una mayor flexibilidad horaria para organizar mis tareas académicas.

También estoy muy satisfecha con el

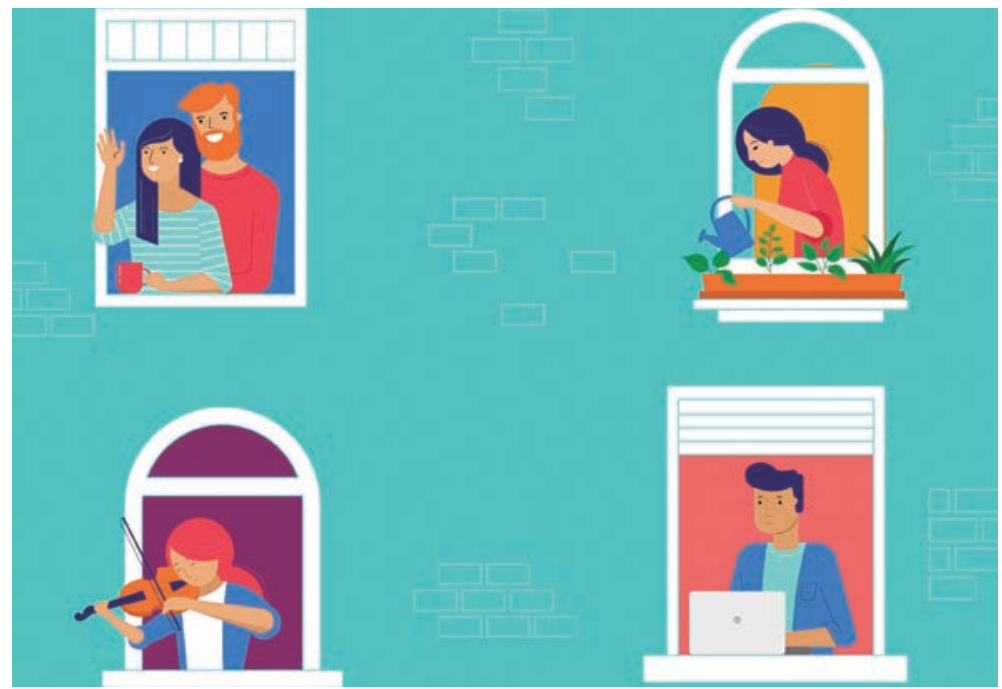
trato recibido por parte de mis profesores. Han mostrado un gran interés y preocupación por la salud de todas nosotras y de nuestras familias, ya sea en sus correos o durante las clases online. Han sabido adaptarse a esta situación y hacerla lo más amena posible para nosotras, reduciéndonos la carga de trabajo cuando ha sido necesario porque nos veíamos apuradas. Y han hecho todo lo posible por continuar la explicación de los contenidos de sus respectivas asignaturas vía online.

En este sentido creo que el formato ha sido satisfactorio, tanto por las plataformas elegidas como por los contenidos desarrollados. Además, he podido apreciar más compañerismo entre nosotras a la hora de resolvernos dudas y de hacer más llevadera esta situación. Sin mencionar también que las tecnologías nos han facilitado mucho el poder estar en contacto, sobre todo a la hora de llevar a cabo trabajos en pareja o en grupo.

Todo en esta vida es un aprendizaje. Por eso me gustaría concluir diciendo que, a pesar de la dureza de esta vivencia, estamos demostrando una gran capacidad de adaptación y superación; por no mencionar los muchos ejemplos de solidaridad que vemos continuamente a nuestro alrededor. Confío en que todo esto nos permita recuperarnos cuanto antes y nos ayude a crecer como sociedad • 


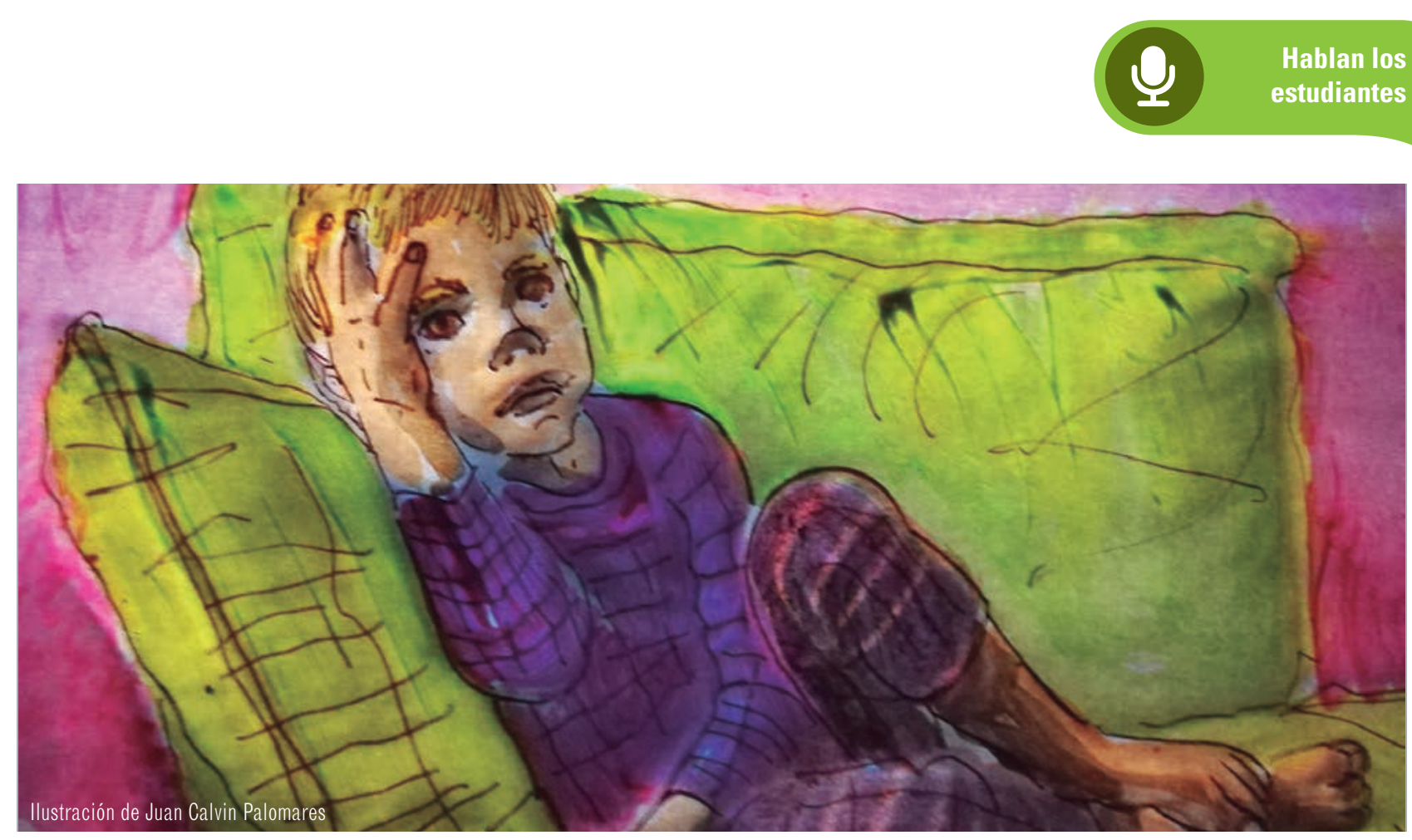

Me presento. Soy Pablo, un estudiante en el último curso del grado de Educación Infantil y Primaria en la Universidad Pontificia Comillas. Aunque si os soy sincero, ya me siento más profesor que estudiante. Y es que, como a muchos de vosotros, la situación del virus me sorprendió en las aulas. Concretamente en una de infantil del colegio Nuestra Señora del Recuerdo, en la que disfrutaba de mis prácticas rodeado de niños y niñas de tres años. En otras palabras, venía de pasar dos meses dando abrazos, besos y caricias, en definitiva, de aprender a amar de los mayores expertos, los niños.

Pero entonces llegó el confinamiento, y la necesidad de guardar un distanciamiento social dentro y fuera de los hogares, especialmente en aquellas familias con algún enfermo o sanitario en primera línea, como es mi caso. Y ahora anhelamos más que nunca ese contacto pues, aunque los adultos seamos especialistas en ocultarlo, lo necesitamos tanto como los niños. Algunas muestras de ello las dan las frecuentes videollamadas con familiares y amigos, los aplausos y las conversaciones vecinales a las ocho, o una vida familiar más intensa que nunca. El contacto ya no es personal, ni las caricias son físicas, pero seguimos demandándolas y recibiéndolas por otros medios.

Esta demanda silenciosa que hacemos los adultos es más evidente y natural en los niños, que ansían volver a jugar con sus amigos, abrazar de nuevo a sus abuelos y hablar de sus anécdotas de cuarentena con sus profesores y profesoras. Todo esto lo expresan a través de las videollamadas, en mi caso no en calidad de profesor, sino de catequista. Es nuestra forma de mantener ese contacto, de que se sientan queridos y conectados, en lugar de aislados. No se pretende hacer una catequesis al uso, sino poderlos acariciar aunque sea de manera virtual, empezando con una pregunta tan sencilla como "¿qué tal estáis?".

En mi opinión, esta crisis mundial ha evidenciado la fragilidad de las seguridades que teníamos como sociedad, y las carencias de un sistema educativo más preocupado en la evaluación que en los alumnos. Pero ojalá esta nueva situación nos ayude a poner en valor la importancia del contacto, y nos conduzca a sentirnos parte de comunidades educativas, religiosas y de vecinos, cada ver más hermanadas y solidarias •
Pablo Cabrero Sánchez

\author{
$\left[5{ }^{\circ}\right.$ Doble Grado de Educación \\ Primaria e Infantil ]
}




\section{Carmen Chichón Criado}

\section{[5. Doble Grado de Educación Infantil y Primaria ]}

Llegaste como una tormenta, con un cielo encapotado dando pequeñas pistas de lo que podría ocurrir. Pero ni los más previsores estaban preparados para el temporal.

Nos pillaste haciendo de nuestra rutina un día más. Algunos en clase, otros corriendo para llegar al trabajo, los más perezosos aún dormían y algunos con menos suerte te esperaban en los hospitales.

Te llevaste por delante los timbres de las clases, la pólvora de las Fallas, los abrazos del día del padre, las salidas de los cofrades con sus pasos, las sevillanas en la feria, el olor a libros en la Cuesta de Moyano, los besos del día de la madre, los chotis de San Isidro, esos partidos que nos tenían en vilo hasta el último gol y el bullicio en las calles que bombean el corazón de la ciudad.

Nos calaste hasta los huesos, no a todos del mismo modo, para unos fuiste una segunda oportunidad y para otros una lucha hasta el último aliento.

Cuando pases, que pasarás, no te habrás llevado las ganas de querernos, la fuerza de la sanidad, el ingenio de los maestros, la ilusión de los más pequeños, la constancia de los estudiantes, las vidas que han llegado, el esfuerzo de los que han arrimado el hombro, los abrazos y besos cubiertos de lágrimas por aquellos que ya no están.

\section{Te llevaste por delante los limbres de las clases, la pólvora de las Fallas, los abrazos del día del padre, las salidas de los cofrades con sus pasos, las sevillanas en la feria, el olor a libros en la Cuesta de Moyano, los besos del día de la madre, los cholis de San Isidro} un montón de malas noticias y normas.
Nos has dado una lección, sin quererlo; el mundo puede pararse, pero ninguno de nosotros va a parar, vamos todos a una, has cerrado fronteras, pero no corazones y, si pretendías distanciarnos, estamos más conectados que nunca.

Invadiste mi vida, sin preguntar, con No sabes quién soy, pero me obligaste a improvisar de la noche a la mañana.

Soy hija, nieta, madrina, prima, novia, amiga, maestra, estudiante, delegada... tantas cosas, que ponerlas en una lista se queda corto. Pero tú te has llevado por delante muchas de ellas: el trabajo de mi padre, la seguridad de mi madre, esas tardes de sofá con los abuelos, darle la mano a mi sobrina en sus primeros pasos, las cosquillas a mis primos, los viajes en coche con la música a todo volumen, las despedidas con besos en la T4, las noches de biblioteca, mis prácticas, las carreras por los pasillos, las visitas cargada con quejas a los despachos, mi graduación... pero ni de lejos me vas arrebatar el valor de la excelencia, mi ilusión por enseñar, el amor por todos los que quiero y me quieren, la fuerza que dan las miradas, un futuro que me espera... Por cada cosa que me has quitado me has dado la oportunidad de valorar otras.

No eres consciente de todo lo que ha sucedido, sucede y sucederá con tu llegada, tu paso y tu partida. Porque tengo la certeza, de que, aunque no nos libremos de ti, el triunfo de esta lucha es nuestro. Y pasarás a ser una de esas historias que recuerde cuando me pregunten: "Abuela, ¿por qué crees en la magia?"• 